\title{
ANXIOLYTIC ACTIVITY EVALUATION OF FOUR MEDICINAL PLANTS FROM CAMEROON
}

\author{
E. Ngo Bum ${ }^{1}$, S. Soudi ${ }^{2}$, E. R. Ayissi ${ }^{2}$, C. Dong ${ }^{2}$, N. H Lakoulo $^{2}$, F. Maidawa ${ }^{2}$, P. F. E. Seke ${ }^{2}$, \\ L. D. Nanga , G. S. Taiwe, T. Dimo ${ }^{2}$, Njifutie Njikam ${ }_{2}$ A. Rakotonirina ${ }^{2}$, S. V. Rakotonirina ${ }^{2}$ \\ and A. Kamanyi ${ }^{2}$.
}

${ }^{1}$ Department of Biological Şciences, Faculty of Sciences, University of Ngaoundéré, P.O. Box 454

Ngaoundéré, Cameroon, epartment of Animal Biology anḑ Physiology, Faculty of Sciences, University of Yaoundé I, P.O. Box 812 Yaoundé, Cameroon, ${ }^{3}$ Department of Animal Biology and Physiology, Faculty of Sciences, University of Dschang, Cameroon.

* Email: elibum@yahoo.fr

\begin{abstract}
Afrormosia laxiflora (A. laxiflora), Chenopodium ambrosioides (C. ambrosioides), Microglossa pyrifolia (M. pyrifolia) and Mimosa pudica (M. pudica) are plants used in traditional medicine in Cameroon to treat insomnia, epilepsy, anxiety, and agitation. They were evaluated for their anxiolytic like activity in mice. Animal models (elevated plus maze and stress-induced hyperthermia tests) were used. The four plants showed anxiolytic activity. In stress-induced hyperthermia test, A. laxiflora, C. ambrosioides, M. pyrifolia and $M$. pudica significantly antagonised the increase of temperature. $\Delta \mathrm{T}^{\circ}$ decreased from $0.75^{\circ} \mathrm{C}$ in the control group to $0.36^{\circ} \mathrm{C}$ at the dose of $110 \mathrm{mg} / \mathrm{kg}$ for A. laxiflora; from $1{ }^{\circ} \mathrm{C}$ in the control group to $-1.1^{\circ} \mathrm{C}$ at the dose of $120 \mathrm{mg} / \mathrm{kg}$ for C. ambrosioides; from $1.7^{\circ} \mathrm{C}$ in the control group to $0.2^{\circ} \mathrm{C}$ at the dose of 128 $\mathrm{mg} / \mathrm{kg}$ for M. pyrifolia and from $1.3^{\circ} \mathrm{C}$ in the control group to $0.5^{\circ} \mathrm{C}$ at the dose of $180 \mathrm{mg} / \mathrm{kg}$ for M. pudica. In the elevated plus maze test, the four plants increased the number of entries into, percentage of entries into, and percentage of time in open arms. A. laxiflora, C. ambrosioides and M. pudica also reduced the percentage of entries and time in closed arms. In addition, C. ambrosioides, M. pyrifolia and $M$. pudica showed antipyretic activity by reducing the body temperature. The results suggested that $C$. ambrosioides, $M$. pyrifolia and $M$. pudica posses anxiolytic-like and antipyretic activities while $A$. laxiflora possesses only anxiolytic-like properties. These plants could be helpful in the treatment of anxiety and fever in traditional medicine in Cameroon.
\end{abstract}

Key words: Anxiety; Agitation; Medicinal plants; Traditional medicine.

\section{Introduction}

Afrormosia laxiflora (Benth) Harms (Fabaceae), Chenopodium ambrosioides Linn (Chenopodiaceae), Microglossa pyrifolia Kuntze (Lam) (Asteraceae) and Mimosa pudica Linn (Mimosaceae), are plants that are being used empirically in traditional medicine in Cameroon and Africa to treat various diseases: agitation, anxiety, insomnia, convulsions, epilepsy, headaches, rheumatism, pains, cold, infectious diseases, diphtheria, worms, malaria, jaundice, yellow fever, diarrhea, dysenteries, amoeba, ulcer, wounds, gonorrhea, constipation, asthma and edema according to the literature and our Traditional Healers (Adjanohoun et al., 1996; Arbonnier, 2000; Dalziel, 1937; Ngo Bum et al., 2009a; Pousset, 1989). The literature also showed a lot of pharmacological studies done with these plants (Amalraj and Ignacimuthu, 2002; Benie and Thieulant, 2004; Ganguly et al., 2007; Gilliy et al., 2008; Haruna, 2000; Jardin et al., 2008; Kumar et al., 2007; Monzote et al., 2007; Ngo Bum et al., 2004; Ngo Bum et al., 2009a; Valsala and Karpagaganapathy 2002). Some of these plants are shown to possess anticonvulsant and sedative properties (Ngo Bum et al., 2004; Ngo Bum et al., 2009a). As it appeared, nothing is done to study their anxiolytic properties though anxiety disorders are the most prevalent mental disorders with very high co-morbidity and severe impact on quality of life (Craske and Waters, 2005; Grant et al., 2005; Kessler, 2007; Kessler et al., 2005). This study was undertaken to evaluate the anxiolytic activity of these plants used also in the treatment of agitations and anxiety in traditional medicine in Africa, particularly in Cameroon.

\section{Materials and Methods Plant material}

A voucher specimen of each of these plants - A. laxiflora (92020/HNC), C. ambrosioides (85040/HNC), M. pyrifolia $(4872 / \mathrm{HNC})$ and $M$. pudica $(54102 / \mathrm{HNC})$ - was authenticated and deposited at the National Herbarium of Cameroon in Yaoundé. For each plan, an amount of plant powder was macerated for $1 \mathrm{~h} \mathrm{in} 50 \mathrm{ml}$ distilled water. The mixture was boiled for $20 \mathrm{~min}$. After cooling, the supernatant (decoction) was collected and filtered using Watman filter paper $\mathrm{N}^{\circ} 1$. A stock solution of each plant was diluted in distilled water to prepare less concentrated solutions. The decoctions were prepared daily according to the instructions of Traditional Healers. In another experiment, the decoction of each plant was evaporated to dryness and the yield of extraction was calculated (Table 1). 


\section{Animals}

Naïve adult male mice, Mus musculus Swiss, $22 \pm 2 \mathrm{~g}$ and two months old obtained from the animal laboratory of our university were used. Animals were housed in standard cages at $25^{\circ} \mathrm{C}$, on a $12 / 12$ hour-light-dark cycle. They were supplied with food and water ad libitum. For each test, mice were divided into 6 groups. One negative control group received distilled water as vehicle, one positive control group received an appropriate well known anxiolytic substance as a reference, and four test groups received different doses of plant extracts. Treatments were administered in a volume of $10 \mathrm{ml} / \mathrm{kg}$ of mice body weight. Specific substances were used as positive control according to the methods. Trials were conducted randomly with respect to treatment condition. Blinded animal experiments were carried out in accordance with the nationally $\left(\mathrm{N}^{\circ}\right.$ FWA-IRB00001954) accepted principles for laboratory animal use and care and the USNRC (1996) Guide for the care and use of Laboratory Animals, US National Research Council, Washington, D.C., United States of America.

\section{Elevated Plus Maze (EPM) test}

The apparatus comprise two open arms $(16 \mathrm{~cm}$ x $5 \mathrm{~cm})$ and two closed arms $(16 \mathrm{~cm} \mathrm{x} 5 \mathrm{~cm} \mathrm{x} 10 \mathrm{~cm})$ that extended from a common central platform $(5 \mathrm{~cm} \mathrm{x} 5 \mathrm{~cm})$. The entire maze was elevated to a height of $50 \mathrm{~cm}$ above floor level. Group I (negative control) was treated with vehicle. Groups II to V (test groups) were treated with 4 doses of the plants extracts. Group VI treated with diazepam, $3 \mathrm{mg} / \mathrm{kg}$ ip was used as positive control. One hour after treatment, the mice were individually placed on the EPM centre platform facing an open arm and observed for 5 min (Bourin et al., 2001; Lister, 1987, Ngo Bum et al., 2009b). The number of entries by each animal into open or closed arms and the time spent by each animal in either open or closed arms (conventional parameters) were recorded with stopwatches. The inner faces of closed arms and the platform were cleaned with alcohol after each mouse recording.

\section{Stress-Induced Hyperthermia (SIH) test}

Naïve animals were marked and housed 10 per treatment or cage. Mice were removed from the cage one after the other in a precise order and treated with vehicle for the negative control group, phenobarbital $(20 \mathrm{mg} / \mathrm{kg}$, i.p. $)$ for the positive control group, and one of the four doses of plant extracts for the test groups. Animals within a given cage were consecutively treated at $1 \mathrm{~min}$ intervals. After $60 \mathrm{~min}$, mice were again consecutively removed from the cage (1-minute interval) and their body (rectal) temperature was recorded. This experiment is based on the fact that among animals in the same cage, mice removed later have a higher body temperature than those removed earlier (Borsini et al., 1989; Lecci et al., 1990). $\operatorname{SIH}\left(\Delta \mathrm{T}^{\circ}\right.$ ) was defined as the difference between the mean temperature of the first three mice and the mean temperature of the last three mice.

\section{Statistical analysis}

The values of the negative control group were compared to the values of the tested groups and positive control group in each test. The analyses of variance (ANOVAs) followed by Dunnett's (HSD) test were used. A p value $<0.05$ was considered significant.

\section{Chemicals}

Diazépam: (Valium ${ }^{\circledR}$, was from Roche, Neuilly, France); Phénobarbital (Sigma Aldrich Inc., St Louis, MO, USA)

Table 1: Details of preparation of plant for intraperitoneal administration.

\begin{tabular}{|l|l|l|l|l|}
\hline Name of the plant & $\begin{array}{l}\text { Part of the plant } \\
\text { used }\end{array}$ & $\begin{array}{l}\text { Quantity plant } \\
\text { powder (g) }\end{array}$ & $\begin{array}{l}\text { Quantity of } \\
\text { water (ml) }\end{array}$ & Yield \\
\hline Afrormosia laxiflora & Dried leaves & 6.67 & 50 & $16.4 \%$ \\
\hline Chenopodium ambrosioides & Dried barks & 15 & 50 & $4 \%$ \\
\hline Microglossa pyrifolia & Dried leaves & 6.67 & 50 & $9.7 \%$ \\
\hline Mimosa pudica & Dried leaves & 20 & 50 & $6 \%$ \\
\hline
\end{tabular}

\section{Results \\ Effect of A. laxiflora}

In EPM, A. laxiflora increased significantly the number of entries into open arms from 0.0 in the control group to 1.9 at the dose of $220 \mathrm{mg} / \mathrm{kg}[\mathrm{F}(6,29)=4.8 ; \mathrm{p}<0.003]$ (Table 2). The percentage of entries into open arms was dose dependently increased from $0.0 \%$ in the control group to $30.6 \%$ at the dose of $220 \mathrm{mg} / \mathrm{kg}[\mathrm{F}(6,29)=6.1 ; \mathrm{p}<0.002]$, as well as the percentage of time spent in open arms from $0.0 \%$ in the control group to $15.7 \%$ at the dose of $220 \mathrm{mg} / \mathrm{kg}[\mathrm{F}(6,29)=$ 113; $\mathrm{p}<0.0001$ ] (Fig 1). As expected for a positive control group, diazepam induced an increase in the percentage of entries and time in open arms. A. laxiflora also induced a light reduction in the percentage of entries and time in closed arms $[\mathrm{F}(6,29)=4.4 ; \mathrm{p}<0.002]$ and $[\mathrm{F}(6,29)=6.1 ; \mathrm{p}<0.001]$, respectively (Fig 2). In addition, the ratio of open entries/total 
entries versus closed entries/total entries strongly and significantly increased with the doses of the decoction $[F(6,29)=4 ; p$ $<0.001]$ (Table 2).

In SIH test, like phenobarbital, A. laxiflora reduced $\Delta \mathrm{T}^{\circ}$ the difference of temperature between the first three mice and the last three mice in a dose dependent manner from $0.75^{\circ} \mathrm{C}$ in the control group to $0.36^{\circ} \mathrm{C}$ at the dose of $110 \mathrm{mg} / \mathrm{kg}$ $[\mathrm{F}(6,29)=18.5 ; \mathrm{p}<0.0001]$ (Fig 3). But A. laxiflora did not affect the body temperature (Table 2).

\section{Effect of C. ambrosioides}

In EPM, C. ambrosioides induced a significant increase in the number of open arms entries from 2.0 in the control group to 3.4 at the dose of $120 \mathrm{mg} / \mathrm{kg}[\mathrm{F}(6,29)=28 ; \mathrm{p}<0.0001]$ (Table 3). The percentage of entries into open arms was dose dependently increased from $26.4 \%$ in the control group to $51 \%$ at the dose of $120 \mathrm{mg} / \mathrm{kg}[\mathrm{F}(6,29)=65 ; \mathrm{p}<0.0001]$, as well as the percentage of time spent in open arms from $7.9 \%$ in the control group to $31.8 \%$ at the dose of $120 \mathrm{mg} / \mathrm{kg}$ $[\mathrm{F}(6,29)=78 ; \mathrm{p}<0.0001]$ (Fig 4). Diazepam also induced an increase in the percentage of entries and time in open arms. Like diazepam, C. ambrosioides induced a significant reduction in the percentage of entries and time in closed arms from $73.5 \%$ and $62.5 \%$ in the control group to $48.9 \%$ and $24.7 \%$ at the dose of $120 \mathrm{mg} / \mathrm{kg}[\mathrm{F}(6,29)=9.2 ; \mathrm{p}<0.001]$ and $[\mathrm{F}(6,29)$ $=102 ; \mathrm{p}<0.0001$ ], respectively (Fig 5). Here also, the ratio of open entries/total entries versus closed entries/total entries strongly and significantly increased with the doses of the decoction $[F(6,29)=14 ; p<0.001]$ (Table 3). In SIH, like phenobarbital, C. ambrosioides strongly reduced $\Delta \mathrm{T}^{\circ}$ from $1.1^{\circ} \mathrm{C}$ in the control group to $-1.1^{\circ} \mathrm{C}$ at the dose of $120 \mathrm{mg} / \mathrm{kg}$ $[\mathrm{F}(6,29)=88 ; \mathrm{p}<0.0001]$ (Fig 6). In addition, C. ambrosioides strongly decreased the body temperature from $36.3^{\circ} \mathrm{C}$ in the control group to $31.0^{\circ} \mathrm{C}$ at the dose of $40 \mathrm{mg} / \mathrm{kg}[\mathrm{F}(6,53)=92 ; \mathrm{p}<0.0001]$ (Table 3$)$.

\section{Effect of M. pyrifolia}

In EPM M. pyrifolia increased the number of open arms entries from 0.0 in the control group to 1.2 at the dose of $64 \mathrm{mg} / \mathrm{kg}[\mathrm{F}(6,29)=89 ; \mathrm{p}<0.0001]$ (Table 4). The percentage of entries into open arms was increased from $0.0 \%$ in the control group to $50.0 \%$ at the dose of $64 \mathrm{mg} / \mathrm{kg}[\mathrm{F}(6,29)=15 ; \mathrm{p}<0.0001]$, as well as the percentage of time in open arms from $0.0 \%$ in the control group to $6.3 \%[\mathrm{~F}(6,29)=108 ; \mathrm{p}<0.0001]$ (Fig 7). Diazepam also induced an increase in the percentage of entries and time in open arms. The percentage of time in closed arms was not affected by M. pyrifolia (Fig 8). In $\mathrm{SIH}, M$. pyrifolia produced in a dose dependent manner a very strong reduction of $\Delta \mathrm{T}^{\circ}$ from $1.7^{\circ} \mathrm{C}$ in the control group to $0.2^{\circ} \mathrm{C}$ at the dose of $128 \mathrm{mg} / \mathrm{kg}[\mathrm{F}(6,29)=52 ; \mathrm{p}<0.0001]$ (Fig 9). In addition, $M$. pyrifolia decreased the body temperature from $29.4^{\circ} \mathrm{C}$ in the control group to $22.6^{\circ} \mathrm{C}$ at the dose of $128 \mathrm{mg} / \mathrm{kg}[\mathrm{F}(6,53)=42 ; \mathrm{p}<0.0001]$ (Table 4).

\section{Effect of M. pudica}

In EPM, M. pudica significantly increased the number of open arms entries from 0.0 in the control group to 1.1 at the dose of $60 \mathrm{mg} / \mathrm{kg}[\mathrm{F}(6,29)=3.3 ; \mathrm{p}<0.05]$ (Table 5). The percentage of entries into open arms was dose dependently increased from $0 \%$ in the control group to $53.3 \%$ at the dose of $180 \mathrm{mg} / \mathrm{kg}[\mathrm{F}(6,29)=10 ; \mathrm{p}<0.0001]$, as well as the percentage of time in open arms from $0.0 \%$ in the control group to $38.3 \%$ at the dose of $60 \mathrm{mg} / \mathrm{kg}[\mathrm{F}(6,29)=10.2 ; \mathrm{p}<$ 0.0001] (Fig 10). M. pudica at the dose of $180 \mathrm{mg} / \mathrm{kg}$ induced a significant reduction in the percentage of entries and time in closed arms from $100 \%$ and $95.6 \%$ in the control group to $46.6 \%$ and $5.8 \%$ at the dose of $180 \mathrm{mg} / \mathrm{kg}[\mathrm{F}(6,29)=9.2 ; \mathrm{p}<$ $0.001]$ and $[\mathrm{F}(6,29)=39.2 ; \mathrm{p}<0.0001]$, respectively (Fig 11). In addition, the ratio of open entries/total entries versus closed entries/total entries strongly and significantly increased with the doses of the decoction $[F(6,29)=4 ; p<0.001]$ (Table 5)

In $\mathrm{SIH}, M$. pudica reduced $\Delta \mathrm{T}^{\circ}$ in a dose dependent manner from $1.3^{\circ} \mathrm{C}$ in the control group to $0.5^{\circ} \mathrm{C}$ at the dose of 180 $\mathrm{mg} / \mathrm{kg}[\mathrm{F}(6,29)=39.2 ; \mathrm{p}<0.0001]$ (Fig 12). The extract also decreased the mice body temperature from $30.5^{\circ} \mathrm{C}$ in the control group to $28.4^{\circ} \mathrm{C}$ at the dose of $18 \mathrm{mg} / \mathrm{kg}$ (Table 5).

\section{Discussion}

The extracts of A. laxiflora, C. ambrosioides, M. pyrifolia and M. pudica antagonized in a dose-dependent manner the hyperthermia induced by stress. This antagonism, close to the effect of phenobarbital, suggests the presence of anxiolytic-like activity in the four plants, since anxiolytic drugs induce inhibition of SIH (Bouwknecht et al., 2007; Ngo Bum et al., 2009b; Olivier et al., 2003; Vinkers et al., 2008). The anxiolytic-like activity was also found in the EPM test where the four plants increased the number of entries into, the percentage of entries and time in open arms, and A. laxiflora, C. ambrosioides and M. pudica reduced in addition the percentage of closed arms entries and time (Lister, 1987; Ngo Bum et al., 2009b; Rodgers et al., 1997). The correlation of the increase in time spent in open arms with the increase in the number of entries in open arms supported the anxiolytic-like activity of the four plants (Lister, 1987; Rodgers et al., 1997). With the four plants, the fact that the entries into open arms were increasing, while the total entries were decreasing or not changing suggested an increase of exploratory activity not related to the locomotion. The increase of the exploration activity, revealed also by the increase of the ratio OE/TE vs CE/TE suggested anxiolytic activity as anti-anxiety drugs decrease the stressinduced the inhibition of exploratory behaviour (File and Wardill 1975; Jenck et al., 1997; Ngo Bum et al., 2009b; Rodgers et al., 1997). The anxiolytic-like activity of these plants could be explained by the presence of some components in the plant extracts interacting with the benzodiazepine/ $\mathrm{GABA}_{\mathrm{A}}$ receptors as agonists, or with the $5-\mathrm{HT}_{1 \mathrm{~A}}$ receptors as agonists, or with the NMDA receptors as antagonists, or with any other mechanisms (Olivier et al., 2003; Tunnicliff, 1991; Vinkers et al., 2008). 
Table 2: The effect of $A$. laxiflora, Open arms entries, closed arms entries, total arm entries and ratio open arms entries/total arms entries (OE/TE) versus closed arms entries/total arms entries (CE/TE) in EPM test; and body temperature in SIH test.

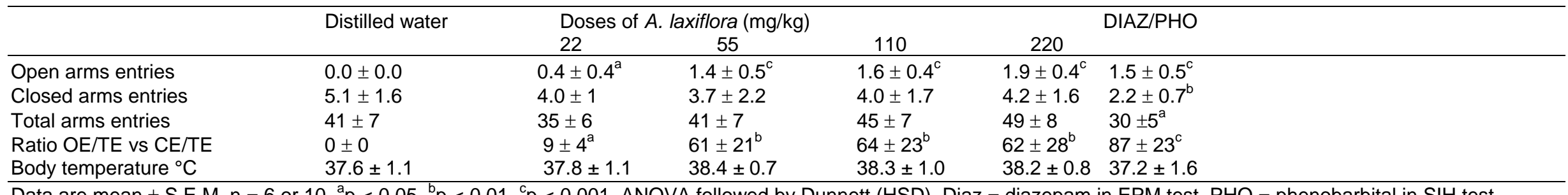

Data are mean \pm S.E.M, $n=6$ or $10,{ }^{a} p<0.05,{ }^{b} p<0.01,{ }^{c} p<0.001$, ANOVA followed by Dunnett (HSD). Diaz = diazepam in EPM test, PHO $=$ phenobarbital in SIH test.

Table 3: The effect of $C$. ambrosioides, Open arms entries, closed arms entries, total arm entries and ratio open arms entries/total arms entries (OE/TE) versus closed arms entries/total arms entries (CE/TE) in EPM test; and body temperature in SIH test.

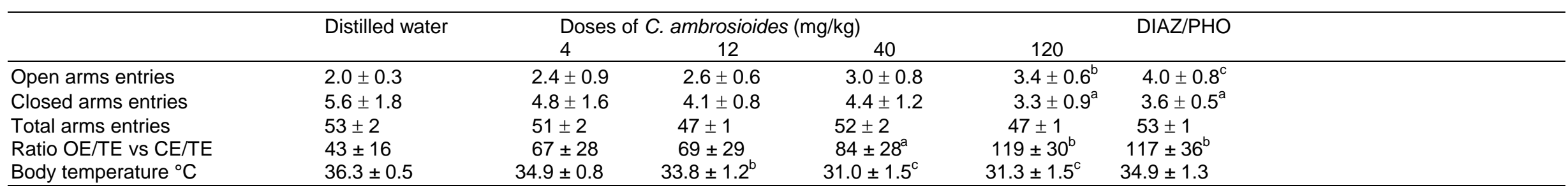

Data are mean \pm S.E.M, $n=6$ or $10,{ }^{a} p<0.05,{ }^{b} p<0.01,{ }^{c} p<0.001$, ANOVA followed by Dunnett (HSD). Diaz $=$ diazepam in EPM test, PHO $=$ phenobarbital in SIH test. 
Table 4: The effect of $M$. pyrifolia, Open arms entries, closed arms entries, total arm entries and ratio open arms entries/total arms entries (OE/TE) versus closed arms entries/total arms entries (CE/TE) in EPM test; and body temperature in SIH test.

\begin{tabular}{|c|c|c|c|c|c|c|}
\hline & \multirow[t]{2}{*}{ Distilled water } & \multicolumn{2}{|c|}{ Doses of $M$. pyrifolia $(\mathrm{mg} / \mathrm{kg})$} & \multirow{2}{*}{\multicolumn{3}{|c|}{ DIAZ/PHO }} \\
\hline & & 12.8 & 32 & & & \\
\hline Open arms entries & $0.0 \pm 0.0$ & $0.0 \pm 0.0$ & $0.1 \pm 0.2$ & $1.2 \pm 0.4^{\mathrm{c}}$ & $0.0 \pm 0.0$ & $1.6 \pm 0.6^{\mathrm{c}}$ \\
\hline Closed arms entries & $6.2 \pm 0.8$ & $4.2 \pm 0.8^{C}$ & $3.7 \pm 0.8^{c}$ & $1.2 \pm 0.4^{\mathrm{C}}$ & $1.09 \pm 0.0^{c}$ & $2.0 \pm 0.5^{c}$ \\
\hline Total arms entries & $50 \pm 1$ & $34 \pm 1$ & $31 \pm 1^{b}$ & $20 \pm 1^{c}$ & $8 \pm 1^{c}$ & $29 \pm 1^{c}$ \\
\hline Ratio OE/TE vs CE/TE & $0 \pm 0$ & $0 \pm 0$ & $3 \pm 1$ & $117 \pm 42^{c}$ & $0 \pm 0$ & $100 \pm 22^{c}$ \\
\hline Body temperature ${ }^{\circ} \mathrm{C}$ & $29.4 \pm 0.9$ & $28.5 \pm 0.3$ & $25.7 \pm 0.7^{\mathrm{b}}$ & $23.9 \pm 0.7^{c}$ & $22.6 \pm 0.2^{c}$ & $30.1 \pm 0.6$ \\
\hline
\end{tabular}

Data are mean \pm S.E.M, $n=6$ or $10,{ }^{b} p<0.01,{ }^{c} p<0.001$, ANOVA followed by Dunnett (HSD). Diaz $=$ diazepam in EPM test, PHO $=$ phenobarbital in SIH test.

Table 5: The effect of $M$. pudica, Open arms entries, closed arms entries, total arm entries and ratio open arms entries/total arms entries (OE/TE) versus closed arms entries/total arms entries (CE/TE) in EPM test; and body temperature in SIH test.

\begin{tabular}{|c|c|c|c|c|c|}
\hline & \multirow[t]{2}{*}{ Distilled water } & \multicolumn{2}{|c|}{ Doses of $M$. pudica $(\mathrm{mg} / \mathrm{kg})$} & \multicolumn{2}{|r|}{ DIAZ/PHO } \\
\hline & & 6 & 18 & 60 & 180 \\
\hline Open arms entries & $0.0 \pm 0.0$ & $0.2 \pm 0.4$ & $0.7 \pm 0.4^{\mathrm{c}}$ & $1.1 \pm 0.4^{\mathrm{c}}$ & $1.0 \pm 0.5^{b}$ \\
\hline Closed arms entries & $5.7 \pm 2.0$ & $5.6 \pm 1.1$ & $5.0 \pm 1.2$ & $3.6 \pm 1.2^{\mathrm{a}}$ & $0.9 \pm 0.9^{c}$ \\
\hline Total arms entries & $46 \pm 2$ & $47 \pm 1$ & $46 \pm 1$ & $38 \pm 1^{\mathrm{b}}$ & $15 \pm 11^{\mathrm{c}}$ \\
\hline Ratio OE/TE vs CE/TE & $0 \pm 0$ & $4 \pm 1$ & $17 \pm 7^{b}$ & $50 \pm 12^{c}$ & $100 \pm 23^{c}$ \\
\hline Body temperature ${ }^{\circ} \mathrm{C}$ & $30.5 \pm 0.6$ & $30.1 \pm 0.8$ & $28.4 \pm 0.6^{\mathrm{a}}$ & $28.7 \pm 0.6^{\mathrm{a}}$ & $28.9 \pm 0.4^{\mathrm{a}} 29.5 \pm 0.9$ \\
\hline
\end{tabular}

Data are mean \pm S.E.M, $n=6$ or $10,{ }^{a} p<0.05,{ }^{b} p<0.01,{ }^{c} p<0.001$, ANOVA followed by Dunnett (HSD). Diaz = diazepam in EPM test, PHO = phenobarbital in SIH test. 
In addition, C. ambrosioides, M. pyrifolia and M. pudica showed antipyretic properties which allowed the body temperature to fall in SIH test (Olivier et al., 2003; Sundgren-Andersson et al., 1998). Some studies are ongoing in our laboratory to determine the mechanism of action of these plants.

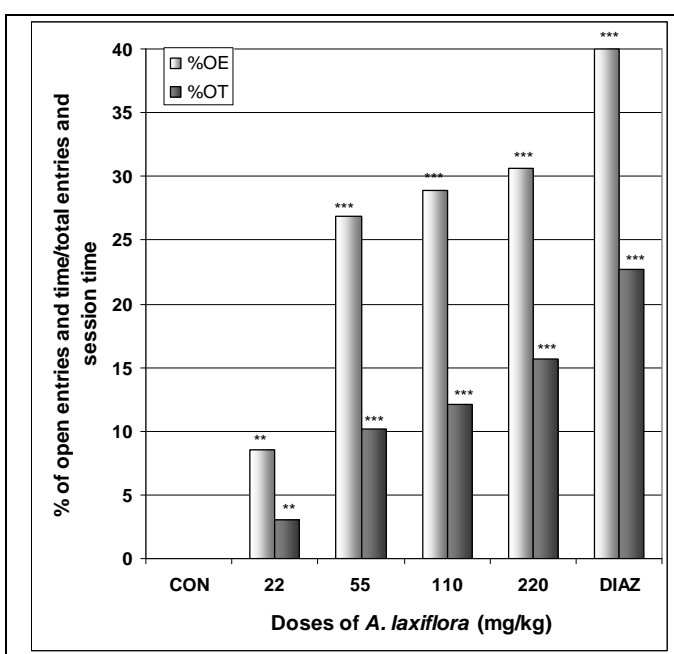

Figure 1: Effect of A. laxiflora in mice placed on EPM; Open arms entries and time

The figure represents the percentage of open arms entries/total arms entries and the percentage of open arms time/session time (5min). $\mathrm{N}=6, * * \mathrm{p}<$ $0.01, * * * \mathrm{p}<0.001$, ANOVA followed by Dunnett (HSD). $\mathrm{CON}=$ negative control, DIAZ $=$ diazepam.

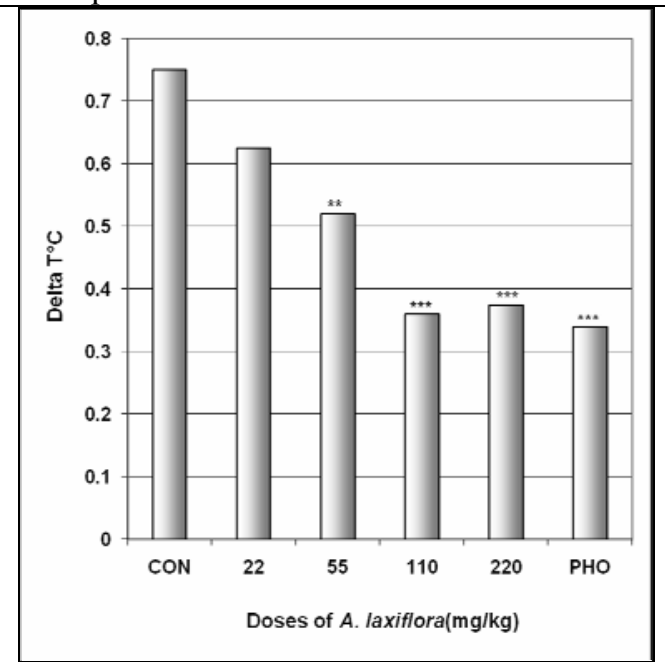

Figure 3: Effect of A. laxiflora in SIH

The figure represents the temperature difference $\left(\Delta \mathrm{T}^{\circ} \mathrm{C}\right)$ between the first three mice and the last three mice. $\mathrm{N}=10, * * \mathrm{p}<0.01, * * * \mathrm{p}<0.001$, ANOVA followed by Dunnett (HSD). CON = negative control, $\mathrm{PHO}=$ phenobarbital.

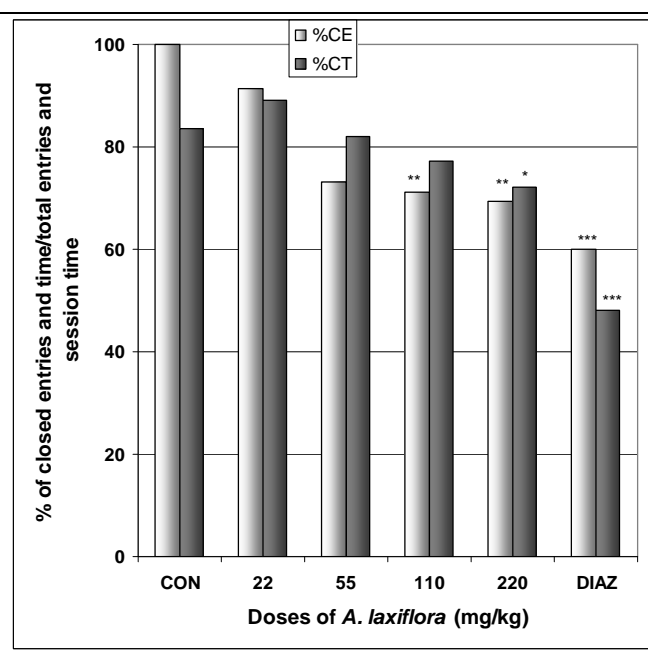

Figure 2: Effect of A. laxiflora in mice placed on EPM; Closed arms entries and time

The figure represents the percentage of closed arms entries/total arms entries and the percentage of open arms time/session time (5min). $\mathrm{N}=6, * \mathrm{p}<0.05, * * \mathrm{p}$ $<0.01, * * * \mathrm{p}<0.001$, ANOVA followed by Dunnett (HSD). $\mathrm{CON}=$ negative control, DIAZ $=$ diazepam.

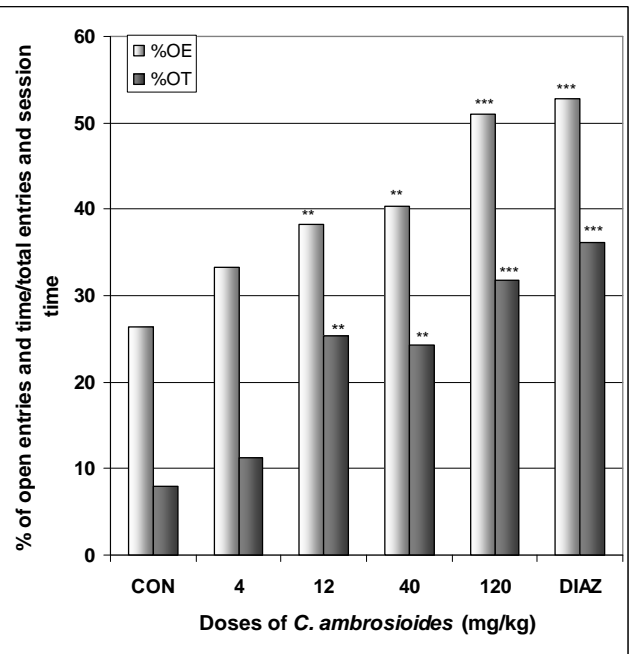

Figure 4: Effect of $C$. ambrosioides in mice placed on EPM; Open arms entries and time.

The figure represents the percentage of open arms entries/total arms entries and the percentage of open arms time/session time (5min). $\mathrm{N}=6, * * \mathrm{p}<0.01$, $* * *$ $\mathrm{p}<0.001$, ANOVA followed by Dunnett (HSD). CON $=$ negative control, DIAZ $=$ diazepam. 


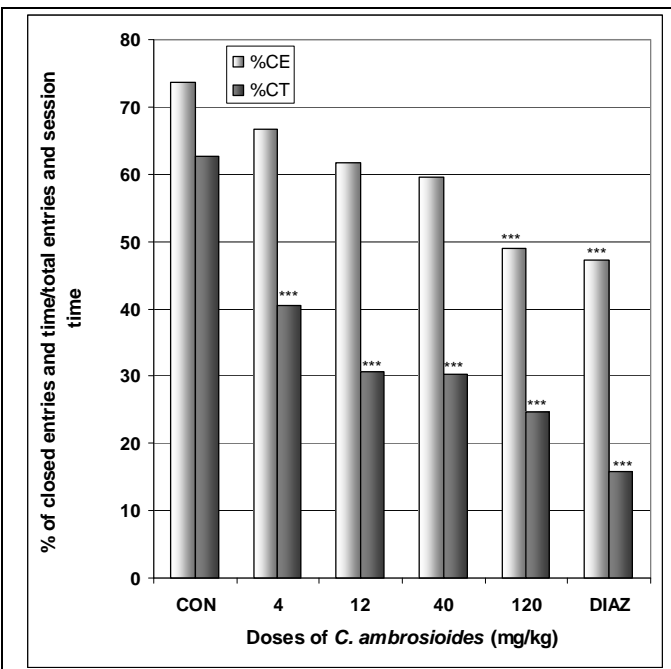

Figure 5: Effect of $C$. ambrosioides in mice placed on EPM; Closed arms entries and time.

The figure represents the percentage of closed arms entries/total arms entries and the percentage of open arms time/session time ( $5 \mathrm{~min}) . \mathrm{N}=6$, $* * * \mathrm{p}<0.001$, ANOVA followed by Dunnett (HSD). $\mathrm{CON}=$ negative control, DIAZ = diazepam.

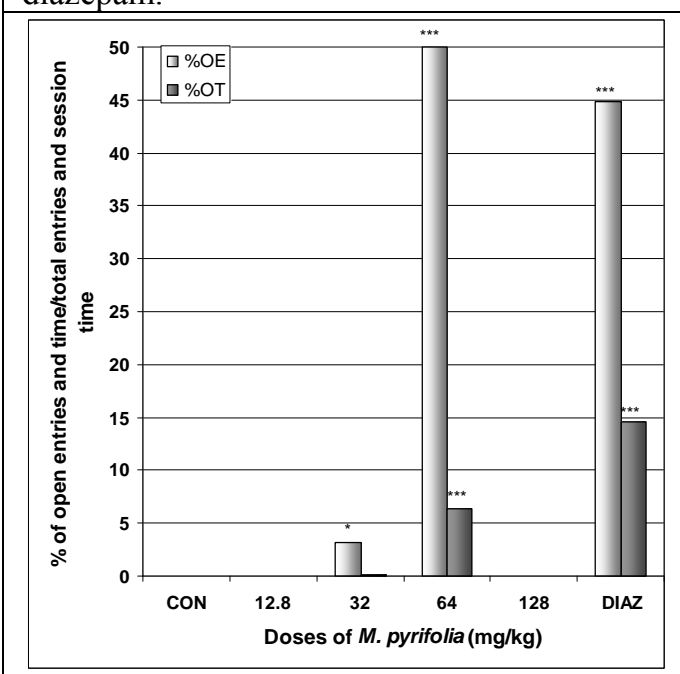

Figure 7: Effect of $M$. pyrifolia in mice placed on EPM; Open arms entries and time.

The figure represents the percentage of open arms entries/total arms entries and the percentage of open arms time/session time (5min). $\mathrm{N}=6, * \mathrm{p}<$ $0.05, * * * \mathrm{p}<0.001$, ANOVA followed by

Dunnett (HSD). CON $=$ negative control, DIAZ $=$ diazepam.

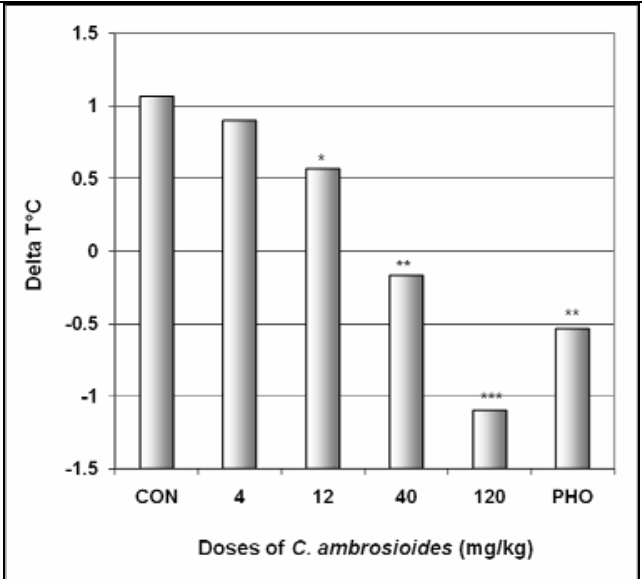

Figure 6: Effect of C. ambrosioides In SIH The figure represents the temperature difference $\left(\Delta \mathrm{T}^{\circ} \mathrm{C}\right)$ between the first three mice and the last three mice. $\mathrm{N}=10, * * \mathrm{p}<0.01$, ANOVA followed by Dunnett (HSD). $\mathrm{CON}=$ negative control, $\mathrm{PHO}=$ phenobarbital.

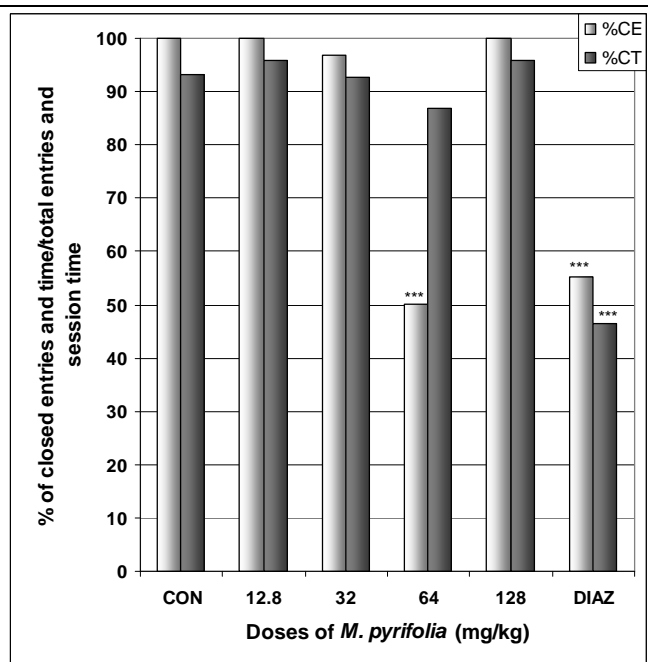

Figure 8: Effect of $M$. pyrifolia in mice placed on EPM; Closed arms entries and time.

The figure represents the percentage of closed arms entries/total arms entries and the percentage of open arms time/session time ( $5 \mathrm{~min}) . \mathrm{N}=6, * * * \mathrm{p}<0.001$, ANOVA followed by Dunnett (HSD). CON $=$ negative control, DIAZ = diazepam. 


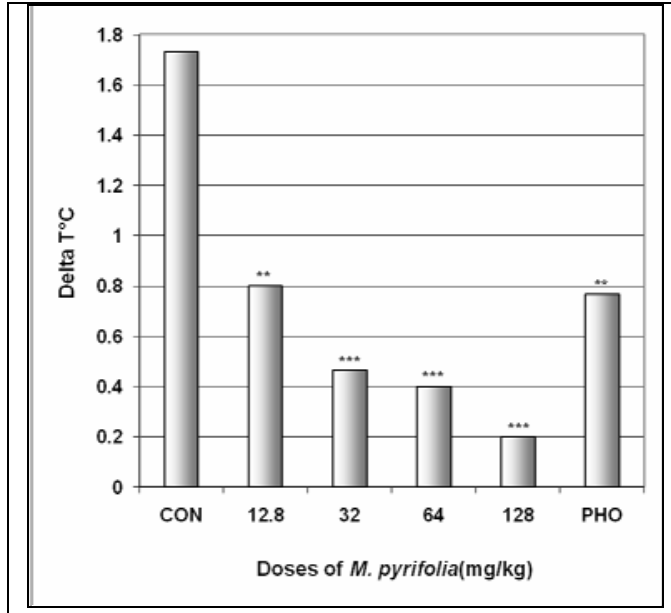

Figure 9: Effect of $M$. pyrifolia in SIH

The figure represents the temperature difference $\left(\Delta \mathrm{T}^{\circ} \mathrm{C}\right)$ between the first three mice and the last three mice. $\mathrm{N}=10, * * \mathrm{p}<0.01, * * * \mathrm{p}<0.001$, ANOVA followed by Dunnett (HSD). CON = negative control, $\mathrm{PHO}=$ phenobarbital.

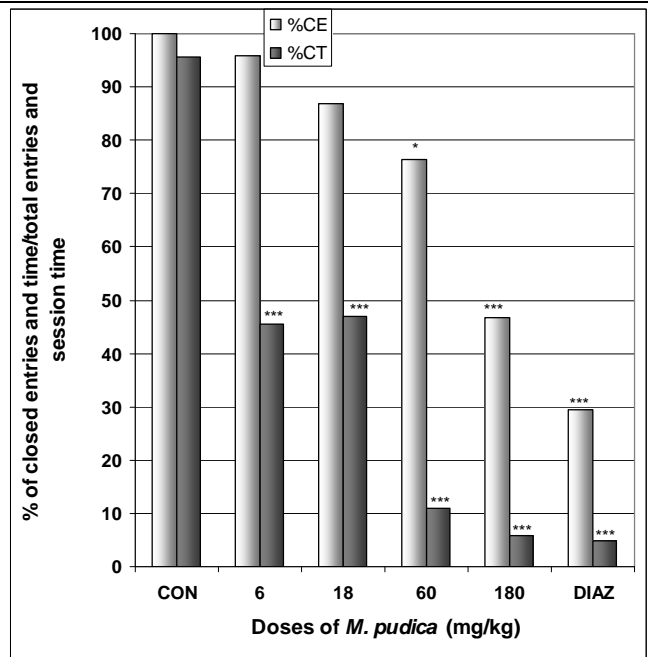

Figure 11: Effect of $M$. pudica in mice placed on EPM; Closed arms entries and time.

The figure represents the percentage of closed arms entries/total arms entries and the percentage of open arms time/session time ( $5 \mathrm{~min}) . \mathrm{N}=6,{ }^{*} \mathrm{p}$ $<0.05, * * * \mathrm{p}<0.001$, ANOVA followed by Dunnett (HSD). CON $=$ negative control, DIAZ = diazepam.

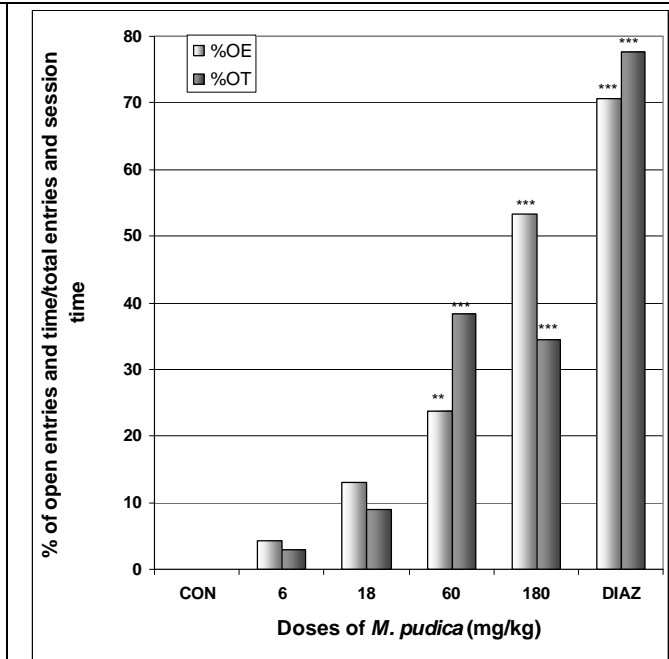

Figure 10: Effect of $M$. pudica in mice placed on EPM; Open arms entries and time.

The figure represents the percentage of open arms entries/total arms entries and the percentage of open arms time/session time (5min). $\mathrm{N}=6, * * \mathrm{p}<$ $0.01, * * * \mathrm{p}<0.001$, ANOVA followed by Dunnett (HSD). CON = negative control, DIAZ = diazepam.

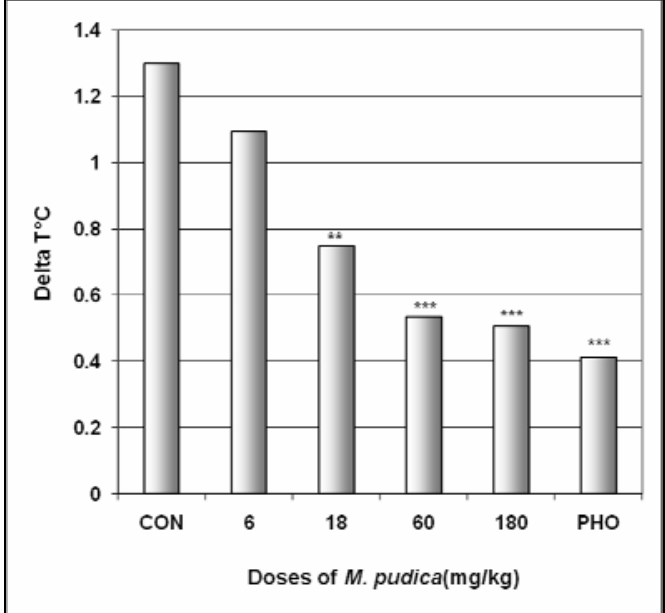

Figure 12: Effect of M. pudica in SIH

The figure represents the temperature difference

$\left(\Delta \mathrm{T}^{\circ} \mathrm{C}\right)$ between the first three mice and the last three mice. $\mathrm{N}=10, * * \mathrm{p}<0.01, * * * \mathrm{p}<0.001$, ANOVA followed by Dunnett (HSD). CON = negative control, $\mathrm{PHO}=$ phenobarbital.

\section{Conclusion}

The purported anxiolytic and/or antipyretic activities of A. laxiflora, C. ambrosioides, M. pyrifolia and M. pudica used in traditional medicine in Cameroon to treat people were demonstrated scientifically. The extracts of C. ambrosioides, M. pyrifolia and M. pudica were shown to posses antipyretic and anxiolytic properties in mice; while the extract of $A$. laxiflora posses only anxiolytic properties. These properties supported the pertinence of the utilization of these plants in traditional medicine in Cameroon in the treatment of fever, agitations and anxiety. 
Abbreviations: Negative control (CON), closed arms entries (CE), closed arms time (CT), diazepam (DIAZ), Elevated plus maze (EPM), open arms entries (OE), open arms time (OT), phenobarbital (Pheno), stress-induced hyperthermia (SIH), total arms entries (TE).

\section{Aknowledgement}

Funding was provided by the University of Ngaoundéré, Cameroon

\section{References}

1. Adjanohoun, J.E., Aboubakar, N., Dramane, K., Ebot, M.E., Ekpere, J.A., Enow- Orok, E.G., Focho, D., Gbile, Z.O., Kamanyi, A., Kamsu-kom, J., Keita, A., Mbenkum, T., Mbi, C.N., Mbiele, A.C., Mbome, J.C., Muberu, N.K., Nancy, W.L., Nkongmeneck, B., Satabie, B., Sofowora, A., Tamze, V., Wirmum, C.K. (1996) Traditional medicine and pharmacopoeia: Contribution to ethnobotanical and floristic studies in Cameroon. Ed. Organization of African Unity Scientific, Technical and Research Commission, Centre National de Production de Manuels Scolaires, Porto-Novo.

2. Amalraj, T., Ignacimuthu, S. (2002). Hyperglycemic effect of leaves of Mimosa pudica Linn. Fitoterapia. 73: 351-352.

3. Arbonnier, M. (2000). Arbres, arbustes et lianes des zones sèches d'Afrique de l'Ouest. Ed. Centre de Coopération Internationale en Recherche Agronomique pour le développement/Muséum national d'histoire naturelle/Union mondiale pour la nature (CIRAD/MNHN/UICN), Paris.

4. Benie, T., Thieulant, M.L. (2004). Mechanisms underlying antigonadotropic effects of some traditional plant extracts in pituitary cell culture. Phytomedicine. 11: 157-164.

5. Borsini, F., Lecci, A., Volterra, G., Meli, A. (1989). A model to measure anticipatory anxiety in mice? Psychopharmacology. 98: 207-211.

6. Bourin, M., Dhonnchadha, B.A., Colombel, M.C., Dib, M., Hascoet, M. (2001). Cyamemazine as an anxiolytic drug on the elevated plus maze and Light/dark paradigm in mice. Behavioral Brain Res. 124: 87-95.

7. Bouwknecht, J.A., Olivier, B., Paylor, R.E. (2007). The stress-induced hyperthermia paradigm as a physiological animal model for anxiety: a review of pharmacological and genetic studies in the mouse. Neurosci. Biobehav. Rev. 31: 41-59.

8. Craske, M.G., Waters, A.M. (2005). Panic disorder, phobias, and generalized anxiety disorder. Annu. Rev. Clin. Psychol. 1: 197-225.

9. Dalziel, J.M. (1937). The useful plants of West Tropical Africa. Ed. The Crown Agency for the Colonies, London.

10. File, S.E., Wardill, A.G. (1975). Validity of head dipping as a measure of exploration in a modified hole board. Psychopharmacologia. 44: 53-59.

11. Ganguly, M., Devi, N., Mahanta, R., Borthakur, M.K. (2007). Effect of Mimosa pudica root extract on vaginal estrous and serum hormones for screening of antifertility activity in albino mice. Contraception. 76: 482-485.

12. Gilliy, Y.G., Gleiser, R.M., Zygadlo ,J.A. (2008). Mosquito repellent activity of essential oils of aromatic plants growing in Argentina. Bioresour. Technol. 99: 2507-2515.

13. Grant, B.F., Hasin, D.S., Stinson, F.S., Dawson, D.A., June Ruan, W., Goldstein, R.B., Smith, S.M., Saha, T.D., Huang, B. (2005). Prevalence, correlates, co-morbidity, and comparative disability of DSM-IV generalized anxiety disorder in the USA: results from the National Epidemiologic Survey on Alcohol and Related Conditions. Psychol. Med. 35: 17471759.

14. Haruna, A.K. (2000). Depressant and anticonvulsant properties of the root decoction of Afrormosia laxiflora (Leguminosae). Phytother. Res. 14: 57-59.

15. Jardin, C.M., Jham, G.N., Dhingra, O.D., Treire, M.M. (2008). Composition and antifungal activity of the essential oil of the Brazilian Chenopodium ambrosioides L. J. Chem. Ecol. 34: 1213-1218.

16. Jenck, F., Moreau, J.L., Martin, J.R., Kilpatick, G.J., Reinsheid, R.K., Monsma, F.J., Nothaker, H.P., Civelli, O. (1997) Orphanin FG acts as an anxiolytic to attenuate behavioural responses to stress. Proc. Natl. Acad. Sci. USA. 94: 1485414858.

17. Kessler, R.C., Berglund, P., Demler, O., Jin, R., Merikangas, K.R., Walters, E.E. (2005). Lifetime prevalence and ageof-onset distributions of DSM-IV disorders in the National Comorbidity Survey Replication. ArchGen. Psychiatry. 62: 593-602.

18. Kessler, R.C. (2007). The global burden of anxiety and mood disorders: putting the European Study of the Epidemiology of Mental Disorders (ESEMeD) findings into perspective. J. Clin. Psychiatry. 68: 10-19.

19. Kumar, R., Mishra, A.K., Dubey, N.K., Tripathi, Y.B. (2007). Evaluation of Chenopodium ambrosioides oil as a potential source of antifungal, antiaflatoxigenic and antioxidant activity. Int. J. Food Microbiol. 115: 159-164.

20. Lecci, A., Borsini, F., Volterra, G., Meli ,A. (1990). Pharmacological validation of a novel animal model of anticipatory anxiety in mice. Psychopharmacolavogy. 101: 255-261.

21. Lister, R.G. (1987). The use of a plus-maze to measure anxiety in mouse. Psychopharmacology. 92: 180-185.

22. Monzote, L., Garcia, M., Montalvo, A.M., Scull, R., Miranda, M., Abreu, J. (2007). In vitro activity of an essential oil against Leishmania donovani. Phytother. Res. 21: 1055-1058.

23. Ngo Bum, E., Dawack, D.L., Schmutz, M., Rakotonirina, A., Rakotonirina, S.V., Portet, C., Jeker, A., Olpe, H.R., Herrling, P. (2004). Anticonvulsant activity of Mimosa pudica decoction. Fitoterapia. 75: 310-315. 
24. Ngo Bum, E., Taiwe, G.S., Nkainsa, L.A., Moto, F.C.O., Seke Etet, P.F., Hiana, I.R., Bailabar, T., Rouyatou, Papa Seyni, Rakotonirina, A., Rakotonirina, S.V. (2009a). Validation of anticonvulsant and sedative activity of six medicinal plants. Epilepsy Behav. 14: 454-458.

25. Ngo Bum, E., Taiwe, G.S., Moto, F.C.O., Ngoupaye, G.T., Nkantchoua, G.C.N., Pelanken, M.M., Rakotonirina, S.V., Rakotonirina, A. (2009b). Anticonvulsant, anxiolytic and sedative properties of the roots of Nauclea latifolia Smith in mice. Epilepsy Behav. 15: 434-440.

26. Olivier, B., Zethof, T., Pattij, T., Van Boogaert, M., Van Oorschot, R., Leahy, C., Oosting, R., Bouwknecht, A., Veening, J., Van der Gugten, J., Groenink, L. (2003). Stress-induced hyperthermia and anxiety: pharmacological validation. Eur. J. Pharmacol. 463: 117-132.

27. Pousset, J.L. (1989). Plantes médicinales africaines. Ed. Marketing, ACCT, Paris.

28. Rodgers, R.J., Cao, B.J., Dalv,i A., Holmes, A. (1997). Animal models of anxiety: an ethological perspective. Braz. J. Med. Biol. Res. 30: 289-304.

29. Sundgren-Andersson, A.K., Östlund, P., Bartfai, T. (1998). Simultaneous Measurement of Brain and Core Temperature in the Rat during Fever, Hyperthermia, Hypothermia and Sleep. NeuroImmunoModulation. 5: 241-247.

30. Tunnicliff, G. (1991). Molecular basis of buspirone's anxiolytic action. Pharmacol Toxicol. 69: 149-156.

31. Valsala, S., Karpagaganapathy P.R. (2002). Effect of Mimosa pudica root powder on oestrous cycle and ovulation in cycling female albino rat, Rattus norvegicus. Phytother. Res.16: 190-192.

32. Vinkers, C.H., Meg, J.V., Bogaert, V., Klanker, M., Mechiel Korte, S., Oosting, R., Hanania, T., Hopkins, S.C., Olivier, B., Groenink, L. (2008). Translational aspects of pharmacological research into anxiety disorders: The stress-induced hyperthermia (SIH) paradigm. Eur. J. Pharmacol. 585: 407-425. 